\title{
Approaches mothers of first graders use to deal with perceived reading difficulties
}

\section{Jana Sedláčková}

Abstract: This study aims to enhance our understanding of how mothers of first graders cope with the perceived reading difficulties of their children. Their different perceptions stem from the reading aspirations the mothers have for their children. The study uses data obtained from in-depth semi-structured interviews with 10 mothers, conducted at the end of the second half of the 2015/2016 school year. The data analysis revealed that the differences in the mothers' perceptions of their children's reading difficulties are reflected in a wide variety of micro-actions aimed at solving them. Three different approaches can be identified: a) inspector mothers, who are most concerned about their child's reading errors and their primary focus is on operationally correcting these errors; b) promoter mothers, who are primarily worried about their child's potential or existing lack of interest in reading and who manage all reading activities so as to motivate the child (or prevent demotivation), e.g., through turn-taking in reading or in ensuring a regular supply of books; c) educator mothers, who fear most that their child will not understand the text and who show willingness and enthusiasm in explaining and creating various opportunities for reading literacy development, both as part of homework activities and leisure reading. They also engage in holistic attempts to prevent reading failures, and motivate their children to read through the act of reading. The conclusions of the study are explained in the context of self-determination theory and a discussion of the impact of parents' socioeconomic status on their involvement or engagement in their children's education.

Keywords: parental involvement, parental engagement, reading difficulties, reading aspirations, self-determination theory, first grade. 


\section{Introduction}

This research paper is anchored in the context of developing reading literacy in students. In both the Czech Republic and internationally, reading literacy has long been perceived as the key ability that enables an individual to functionally and meaningfully deal with all kinds of written texts (Eurydice, 2011; Janotová, Tauberová, \& Potužníková, 2017; Výzkumný ústav pedagogický v Praze, 2011a, b) and thus enables to the individual to actively develop oneself and also to develop a society in which he/she lives and is a part of. In this context reading literacy development is one of the main goals of education, especially at the primary education (Švrčková \& Šimik, 2012) level, where it is necessary to consolidate the foundations. In this paper, however, we not only investigate reading literacy as an ability, but (partly for the purposes of further pedagogical research) look at aspects that are sometimes seen only as being closely related or to run in parallel, such as approaches and attitudes towards reading or the value of reading, which is perhaps (more) socially situated (Da Silva, 2017).

There is a long tradition in the Czech education system of emphasizing reading development and on being a reader, and the concept of reading literacy has always been present in one way or other. However, in line with European trends this concept is still expanding, deepening and interconnecting with other areas of learning. It has received more attention since the beginning of the millennium, when the Czech Republic first participated in comparative international surveys of reading literacy: PIRLS (organized by the IEA) and PISA (organized by the OECD). Despite this, as Wildová notes (2012b), we still lack a conception and strategy for developing and supporting reading literacy at various levels, which would help us reduce the proportion of students with reading difficulties and minimize the risk of social exclusion (Ronková \& Laufková, 2017). At the same time, there have been critical voices highlighting the fact that the Czech Republic lags behind on informal cooperation between teachers and parents (Wildová, 2012a) and the need for quality parental involvement in the formation of a family environment that stimulates reading (Ronková \& Laufková, 2017; Mertin, 2010).

\section{Parental Approaches to Developing Children's Reading Literacy}

The issue of parental involvement in children's learning is attracting more research attention. This also applies to research on reading literacy, an area seen by many as being largely family-dependent (Gorčíková \& Šafr, 2016; 
Najvarová, 2008; Silinskas et al., 2013; Sotáková in Kucharská et al., 2015; Šauerová, 2012, cf. Desforges \& Abouchaar, 2003). By exerting their influence in this area, parents have the opportunity to contribute to the overall success of their child in school. There is a lack of research on home literacy development in children in grades 1 and 2 in the Czech Republic. Yet, this is the period when children receive the greatest support in Czech lessons from both teachers (Wildová, 2012b) and parents alike (Rabušicová, Šedová, Trnková, \& Čiháček, 2004). This support continues to play a significant role (Kucharská \& Seidlová Málková, 2012; Švrčková \& Šimik, 2012). The intention of this study is to fill the gap at least in part. In this context reading literacy development is seen as a continuous process of change within a set of knowledge, skills and abilities as well as in approaches, attitudes and values, that allows individuals to functionally and meaningfully deal with all kinds of written texts (cf. Mareš, Průcha, \& Walterová, 2003; Najvarová, 2008; Výzkumný ústav pedagogický v Praze, 2011a, b; Rabušicová, 2002). Development support refers to any communication and interaction instigated by the parent as part of reading activities (i.e., parent-child activities connected with reading) (Desforges \& Abouchaar, 2003; Leseman \& de Jong, 1998).

In the Czech Republic, analysis into parental influence on specific characteristics of reading literacy development in children has been performed by Sotáková (in Kucharská et al., 2015), who found that parents are well aware of the importance of reading throughout the educational process but do not always have enough information to pursue it purposefully. Ronková and Laufková (2017) add that parents would appreciate guidance on this. Reading literacy development is thought to be largely intuitive, despite being directed by school requirements (see also Gorčiková \& Šafr, 2016).

The foreign literature generally identifies two different ways in which parents participate in their children's education and learning: a) parental engagement, where the degree and a way of involvement is more or less down to the parents - as against the spontaneous involvement described by Desforges and Abouchaar (2003); and (b) parental involvement, where the school or other actors involve the parents in their child's education to be contrasted with the intervention-based involvement in Desforges and Abouchaar (2003) - the difference lies in the degree of parent's intrinsic or external motivation to participate. Numerous sources indicate that the degree or mode of parental participation is significantly influenced by socioeconomic status, especially education level (e.g., Katrňák, 2004; Ndebele, 2015; Pospíšilová, 2011; Silinskas, Leppanen, Aunola, Parrila, \& Nurmi, 2010; Trávníček, 2007; Van Steensel, 2006), while some others argue the 
opposite (e.g., Dumont, Trautwein, Nagy \& Nagengast, 2014; Sotáková in Kucharská, 2015; Stuart, Dixon, Masterson \& Quinlan, 1998). Yet others, such as De Garmo et al. (1999 in Desforges \& Abouchaar, 2003), Niklas and Schneider (2013) or Wu and Honig (2010) point to the indirect influence socioeconomic status has on participation, which can be mediated through parental knowledge and skills (Pospišilová, 2011), different levels of social interaction with the child (Šauerová, 2012) or by expressing an interest for example (Zellman \& Waterman, 1998 in Desforges \& Abouchaar, 2003).

Melhuish et al. (2001 in Desforges \& Abouchaar, 2003) consider the types of specific activities that parents do with their children to support reading literacy development to be part of the home learning environment (HLE) and to include reading, visiting libraries, playing with letters, numbers and shapes, painting and drawing, playful learning of letters and rhymes and singing. According to Leseman and de Jong (1998), however, the HLE can be perceived not simply in the sense of formalized activities, but also as finer, less obvious or clear-cut parental behaviours that create a framework for and regulate these activities - for instance learning opportunities, the quality of instructions, the quality of cooperation and socio-emotional quality of joint interactions between mother and child (Sedláčková, 2017). However, there is hardly any research on how parental approaches differ from one another with regard to this behaviour.

Hoover-Dempsey and Sandler (1995; 1997; Walker, Wilkins, Dallaire, Sandler, \& Hoover-Dempsey, 2005) point out that parents' expectations about what they should do to promote their child's education are at the core of parental involvement (see also Bennet et al., 2002 in Gorčíková \& Šafr, 2016). These expectations help parents identify and determine which activities they should perceive as important and which, conversely, may not be so important. These (albeit unconscious) individual decisions may form the basis on which the parents construct their role in supporting their child's reading literacy. In addition to expectations, Hoover-Dempsey and Sandler (1995; 1997; Walker et al., 2005) note that parental involvement is also influenced by their sense of self-confidence and self-efficacy, associated with how they manage to help their children to learn, and by their perception of the requests, invitations or opportunities for involvement from the school, teachers and the children themselves who may request their help or support (see also Fan, 2012; Green et al., 2007 in Yotyodying \& Wild, 2014).

According to some scholars (Gonida \& Cortina, 2014; Renshaw \& Gardner, 1990; Yotyodying \& Wild, 2014, cf. Lynch, Anderson, Anderson, \& Shap- 
iro, 2006), we can distinguish between parents who are oriented toward the learning process (mastery goal), who encourage their children's autonomy in learning, are less directive and prefer to correct their children's errors indirectly on the one hand, and parents oriented towards learning outcomes (performance goal), who focus more on partially acquired skills and show a higher degree of directivity, control and direct interventions on the other. Some (Froiland, 2011; Dumont, Trautwein, Nagy, \& Nagengast, 2014; Yotyodying \& Wild, 2014) argue that parental involvement that encourages children's autonomy can foster positive emotions related to learning in children.

\section{Various Concepts of Parental Reading Aspirations for their Children}

Parental reading aspirations, or in other words the expectations and longterm goals they have in relation to their children's reading, play a key role in the various forms of parental involvement in the development of children's reading literacy (Lynch et al., 2006; Stephenson, Parrila, Georgiou \& Kirby, 2008; Yeo, Ong \& Ng, 2014). These expectations and goals are closely related to the significance parents attach to their children's reading (Sedláčková, 2017).

The function of parental aspirations in the context of the specific activities and actions they perform to help develop reading literacy can be explained by self-determination theory (Ryan \& Deci, 2017; Wild, 1999 in Yotyodying \& Wild, 2014, pp. 98-99; cf. also Cunha et al., 2015). Parental support can be effective only to the extent that it meets the child's basic needs: autonomy, mutuality and competence. If these needs are met, the child will be able to internalize even uninteresting but socially prescribed activities, such as doing homework or reading, as a personally important behaviour. In relation to this theory, four dimensions of parental support for reading literacy development can be considered: a) promoting autonomy (e.g., encouraging independent reading, providing explanations); b) degree of response ${ }^{1}$ (e.g., dedicating time to reading activities, providing books, discussing with the child); c) structure (e.g., the formulation of clear rules for learning situations and expectations of the child's reading results); and d) control (e.g., supervision of correction of reading errors, guidance on leisure reading, setting criteria for texts to be read by the child). Parents can model the child's approach to reading activities through these dimensions (whether they are aware of it or not).

Clingenpeel and Pianta (2007) found that mothers develop maternal sensitive responding when their child is still at an early age through joint interactions and that the quality of this then significantly influences the amount and quality of literacy-related information acquired by the child. 
Silinskas et al. (2013) stress that the mothers in their sample demonstrably supported the development of their children's reading skills, using both a high degree of controlling behaviour and positive emotional support in the learning situations (see also Kiuru et al., 2012). However, it remains unclear what parents with different reading aspirations do to promote the four dimensions of autonomy, degree of response, structure and control.

Some scholars categorize parental aspirations as being "higher" or "lower" (e.g., Audet, Evans, Williamson \& Reynolds, 2008, Catsambis, 2001 in Desforges \& Abouchaar, 2003, Gonida \& Cortina, 2016; Wu \& Honig, 2010; Yubero Jimenez \& Larañaga Rubio, 2010), where parents with "higher" aspirations tend to encourage the children to retain the same levels parents were used to attain when they were at school. When applied to reading literacy, this involves the creation of richer and more challenging learning opportunities, more frequent reading and literature recommendations for the child, and a joint dialogue about the text that helps children develop their vocabulary. In this sense, Gorčiková and Šafr (2016), as well as Wu and Honig (2010), directly link "higher" aspirations with more educated parents. On the other hand, Sacker et al. (2002 in Desforges \& Abouchaar, 2003) state that as the children of parents with "lower" aspirations make progress, parental expectations also increase (cf. Sénéchal \& LeFevre, 2014, who report that $76 \%$ of the parents surveyed performed activities or adjusted activities in relation to the child's school results). Drawing on this research, in a previous paper (Sedláčková, 2017), I identified three qualitatively different reading aspirations among the mothers in my data that could not easily be ranked from "lowest" to "highest", since each concerned the development of different reading literacy areas: a) mothers with practical reading aspirations wanted their children to master reading well enough for use in everyday life; (b) mothers with experiential reading aspirations wanted their children to enjoy reading and to develop a positive relationship with books and reading; c) mothers with developmental reading aspirations thought it important for their children to acquire reading skills as a value for further development. There can be some overlaps in these different types of aspirations, but only partial.

\section{Parental Perceptions of Children's Reading Difficulties}

Parental approaches to developing reading literacy may also vary depending on the reading difficulties they perceive in their children over time. Gough (1996) states that for some children reading is a more natural activity than it is for others. As children develop, they may experience difficulty in decoding (transforming graphemes into phonemes and linking them to- 
gether in words) or language comprehension (inadequate understanding of how language works, poor language memory or vocabulary), both of which can affect the quality of reading comprehension. Other difficulties may be related to the accuracy, speed and fluency of reading or overall progress in reading (Kucharská et al., 2015, Law, Vandermosten, Ghesquière, \& Wouters, 2017; Siegel, 2006; Speece \& Ritchey, 2005; Speece et al., 2010; Speece et al., 2011). In the Czech Republic, much attention is being devoted to reading comprehension difficulties (as a result of comparatively lower student scores on the PISA and PIRLS tests) (Wildová, 2012b; Wildová, Kropáčková, \& Kucharská, 2014). In addition to these problems, the mothers in my research (Sedláčková, 2017) also mentioned a lack of interest in reading, which on one hand could extend beyond the scope of the list provided above, but on the other could be seen as possibly permeating it.

Case et al. (2010) argue that parents are able to assess their child's reading skills relatively accurately. A questionnaire-based survey by Presslerová and Kucharská (2017) found that parents whose children were about to enter first grade and who did not appear to be at risk of developing a learning disorder were most commonly concerned about inaccurate reading (guessing words) and a failure to combine letters into syllables. This was interpreted as the result of the child's reluctance to do home preparation, whereas parents attributed the same problems in children with an identified risk of developing a reading disorder to a lack of concentration.

Klicpera, Klicpera and Schabmann (2001) state in their research that parents who perceived their children to be weaker readers thought they had motivation problems with homework and reading generally. They also highlighted the risk that parents might internalize the child's perceived problems and that this could affect parental behaviour during home reading activities because their perception was of a "child with reading difficulties". This perspective can be exacerbated by feelings of frustration experienced when trying to help the child and concern about future achievement (Bonifacci, Montuschi, Lami, \& Snowling, 2014; Hughes, Schumm, \& Vaughn, 1999; Presslerová \& Kucharská, 2017; Sedláčková, 2017).

According to Johnson, Bornman and Alant (2010) (see also Stainthorp $\&$ Hughes, 2000) the reading environments of children with and without reading difficulties do not differ significantly, not even in terms of parental approach. The parents they surveyed thought the differences were reflected in their children's responses to reading-related activities, with children with no reading difficulties becoming more engaged in these activities. Vellutino, 
Fletcher, Snowling and Scanlon (2004), on the other hand, argue that the reason many poor readers have reading difficulties is that they receive inadequate instructions from adults. However, asking which came first - "the chicken or the egg" - seems to be less useful than thinking about how this circle of negative experience can be stopped or spun in the opposite direction. To this end, it is necessary first to find out what parents think of their own participation in joint reading activities with their children, which experiences they describe as successful or problematic and why, and what types of their own behaviour do they mention in connection with them.

\section{Research Methodology}

This study is part of a wider research project aimed at understanding how mothers of first graders help their children develop reading literacy. My goal in this paper is to understand how mothers of first grade students reflect on their involvement in dealing with the reading difficulties they perceive in their children. I discuss these reading problems in more detail in another article (see Sedláčková, 2017), in which I also point out that mothers' perceptions of a reading problem differ according to the reading aspirations they hold for their children (see Table 1). This paper builds on that previous study and concretizes the mothers' approaches in terms of their own thoughts on their reading activities behaviour.

I draw the necessary data from the same set of ten in-depth semi-structured interviews with mothers ${ }^{2}$ of children attending grade 1 in two different standard elementary schools ${ }^{3}$ during the second half of the 2015-2016 school year. The sample consisted of five pairs of mothers and children from each school; each pair was from the same class in each school. Since a qualitative research methodology was used, I compiled the sample gradually (Švařiček \& Šed’ová, et al., 2007), using the following criteria: 1) the

2 The focus on mothers was not entirely deliberate - but in all the families surveyed it was the mothers who said they devoted the most time to helping with their children's reading literacy.

3 Specifically, the research concerned two different classes - this was determined by the fact the first line of research was to track the approaches taken by two mothers with different levels of education to developing their child's reading literacy throughout the school year (these mothers had children in different schools); this stage was followed by the second line of research which was to supplement and expand the data already obtained by including other mother-child pairs from the same classes. This was to insure the children were taught by the same teacher in order to avoid the results being influenced by different approaches to literacy (if the pairs had been selected from different classes, the research results could potentially be affected by the different approaches of other teachers). Note: Classroom literacy teaching was not monitored. 
child started attending grade 1 in September 2015; 2) the mothers had different levels of education ${ }^{4}$, 3) the mothers agreed to cooperate by participating in interviews and making audio recordings of reading-based joint activities with their child. ${ }^{5}$ The first mothers interested in participating were recruited through contacts of my acquaintances (availability sampling). The teachers of the two classes attended by the children of these mothers then assisted in recruiting the remaining mothers (snowball sampling). The resulting number of informants was determined by the number of mothers of children in the same two classes that I eventually managed to win over by the end of the school year.

Table 1 Information on the cases ${ }^{6}$

\begin{tabular}{|c|c|c|c|c|c|}
\hline & $\begin{array}{c}\text { Mother- } \\
\text { child } \\
\text { (names } \\
\text { were ano- } \\
\text { nymised) }\end{array}$ & $\begin{array}{c}\text { Mother's } \\
\text { education }\end{array}$ & $\begin{array}{c}\text { Mother's } \\
\text { relationship to } \\
\text { reading (based } \\
\text { on interview) }\end{array}$ & $\begin{array}{c}\text { Mother's } \\
\text { reading } \\
\text { aspiration for } \\
\text { her child (see } \\
\text { Sedláčková, } \\
\text { 2017) }\end{array}$ & $\begin{array}{c}\text { Perceived } \\
\text { reading } \\
\text { difficulty } \\
\text { (see } \\
\text { Sedláčková, } \\
\text { 2017) }\end{array}$ \\
\hline 1. & $\begin{array}{l}\text { Danka - } \\
\text { Domík }\end{array}$ & $\begin{array}{l}\text { University, } \\
\text { faculty of law }\end{array}$ & $\begin{array}{l}\text { Likes reading } \\
\text { and reads often }\end{array}$ & $\begin{array}{l}\text { Developmen- } \\
\text { tal }\end{array}$ & $\begin{array}{l}\text { Misunder- } \\
\text { standing the } \\
\text { text }\end{array}$ \\
\hline
\end{tabular}

4 This criterion was selected since there has been much discussion of whether parental education level directly influences parental involvement in a child's learning, including reading literacy.

5 I am now starting to analyse the audio recordings and I later intend to analyse the results in conjunction with the data obtained in the interviews.

6 It is evident that the relationship between a mother's education level and their reading aspirations is not straightforward - developmental or practical reading aspirations could be associated with a higher or lower education level, but equally having attended higher education or a university-oriented secondary education (gymnazium) does not necessarily indicate the mother in fact has developmental reading aspirations (Simona, Tamara, Tána). Indeed, it seems that the mothers' relationship to reading is more closely related to their reading aspirations for their children and can explain them better. Besides the mother's education level, it is also interesting to consider the number of books in the home when considering the effects the family's socioeconomic status (SES) have on the wider context of the home reading environment. In this survey, however, it turned out to be a somewhat coarse and simplistic variable, as some of the mothers with developmental aspirations (Danka, Tamara) tended to borrow books from public libraries. The role played by frequency of reading, which could be a more accurate indicator (see also Janotová, Tauberová, \& Potužníková, 2017), brings me back to the more subtle factor of the mother's relationship to reading. The quality of the home reading environment of two of the mothers in the sample may have been negatively affected by their sole-earner status, an SES factors (Marika, Martina), while Štěpánka and Zuzana had broader family support networks (active involvement of grandparents in developing the child's reading literacy) and this could be seen as a positive element, even though it is not normally perceived as part of SES. It is a more subtle factor, like the mother's relationship to reading. 


\begin{tabular}{|c|c|c|c|c|c|}
\hline 2. & $\begin{array}{l}\text { Zuzana - } \\
\text { Zorinka }\end{array}$ & $\begin{array}{l}\text { PhD, veteri- } \\
\text { nary univer- } \\
\text { sity }\end{array}$ & $\begin{array}{l}\text { Likes reading } \\
\text { and reads often } \\
\text { (in foreign lan- } \\
\text { guages too) }\end{array}$ & $\begin{array}{l}\text { Developmen- } \\
\text { tal }\end{array}$ & $\begin{array}{l}\text { Misunder- } \\
\text { standing the } \\
\text { text }\end{array}$ \\
\hline 3. & $\begin{array}{l}\text { Simona - } \\
\text { Samik }\end{array}$ & $\begin{array}{l}\text { University, } \\
\text { faculty of } \\
\text { economics }\end{array}$ & Likes reading & Experiential & $\begin{array}{l}\text { Child's lack } \\
\text { of interest in } \\
\text { reading }\end{array}$ \\
\hline 4. & $\begin{array}{l}\text { Marika - } \\
\text { Monča }\end{array}$ & $\begin{array}{l}\text { Secondary } \\
\text { vocational } \\
\text { school, tex- } \\
\text { tiles }\end{array}$ & $\begin{array}{l}\text { Formerly a keen } \\
\text { reader, but now } \\
\text { a mother finds } \\
\text { no time to read }\end{array}$ & Practical & $\begin{array}{l}\text { Child making } \\
\text { reading errors }\end{array}$ \\
\hline 5. & $\begin{array}{l}\text { Martina - } \\
\text { Milánek }\end{array}$ & $\begin{array}{l}\text { Secondary } \\
\text { vocational } \\
\text { school, con- } \\
\text { fectioner }\end{array}$ & $\begin{array}{l}\text { Formerly a keen } \\
\text { reader of girls' } \\
\text { romances, but } \\
\text { finds no time to } \\
\text { read now }\end{array}$ & Practical & $\begin{array}{l}\text { Child making } \\
\text { reading errors }\end{array}$ \\
\hline 6. & $\begin{array}{l}\text { Táňa - } \\
\text { Tonička }\end{array}$ & $\begin{array}{l}\text { Gymnazium } \\
\text { (academic } \\
\text { secondary } \\
\text { school) }\end{array}$ & $\begin{array}{l}\text { Suspects she } \\
\text { might be dyslex- } \\
\text { ic, feels she does } \\
\text { not read well, } \\
\text { embarrassed } \\
\text { when reading in } \\
\text { front of others, } \\
\text { does not like } \\
\text { reading }\end{array}$ & Practical & $\begin{array}{l}\text { Child making } \\
\text { reading errors }\end{array}$ \\
\hline 7. & $\begin{array}{l}\text { Štěpánka } \\
\text { - Šimonek }\end{array}$ & $\begin{array}{l}\text { PhD, faculty } \\
\text { of mathemat- } \\
\text { ics and phys- } \\
\text { ics, meteorol- } \\
\text { ogy }\end{array}$ & $\begin{array}{l}\text { Childhood dys- } \\
\text { lexia that she } \\
\text { has overcome } \\
\text { using drills, likes } \\
\text { reading }\end{array}$ & $\begin{array}{l}\text { Developmen- } \\
\text { tal }\end{array}$ & $\begin{array}{l}\text { Misunder- } \\
\text { standing text } \\
\text { read }\end{array}$ \\
\hline 8. & $\begin{array}{l}\text { Tamara - } \\
\text { Tomášek }\end{array}$ & $\begin{array}{l}\text { Agricultural } \\
\text { secondary } \\
\text { school }\end{array}$ & $\begin{array}{l}\text { Did not like read- } \\
\text { ing as a child, } \\
\text { now enjoys it }\end{array}$ & Experiential & $\begin{array}{l}\text { Child's lack } \\
\text { of interest in } \\
\text { reading }\end{array}$ \\
\hline 9. & $\begin{array}{l}\text { Sofie - } \\
\text { Stelinka }\end{array}$ & $\begin{array}{l}\text { Tertiary tech- } \\
\text { nical school, } \\
\text { physiotherapy }\end{array}$ & $\begin{array}{l}\text { Likes reading } \\
\text { and reads often; } \\
\text { she considers her } \\
\text { family a reading } \\
\text { family }\end{array}$ & $\begin{array}{l}\text { Developmen- } \\
\text { tal }\end{array}$ & $\begin{array}{l}\text { Misunder- } \\
\text { standing text } \\
\text { read }\end{array}$ \\
\hline 10. & $\begin{array}{l}\text { Kristýna - } \\
\text { Karolínka }\end{array}$ & $\begin{array}{l}\text { Secondary } \\
\text { school, busi- } \\
\text { ness academy }\end{array}$ & $\begin{array}{l}\text { Dyslexia; does } \\
\text { not like reading }\end{array}$ & Practical & $\begin{array}{l}\text { Child making } \\
\text { reading errors }\end{array}$ \\
\hline
\end{tabular}

The research design of this study is exploratory-explanatory (cf. Bhattacherjee, 2012; Maxwell \& Mittapalli, 2008; Stebbins, 2001). It is exploratory because the core topic is specific manifestations of the meanings mothers assign to their children's reading, which is a phenomenon that has not yet been fully explored; and it is explanatory because the purpose of the study 
is to explain and understand this phenomenon (not simply describe it), looking at its causes and consequences. It also seeks to uncover and clarify any possible hidden connections relating to the issue.

As mentioned earlier, the research objectives were achieved using qualitative in-depth interviews (see, for example, Švařiček \& Šed’ová, et al., 2007). The interviews were structured around nine thematic areas which mapped the experiences, attitudes, views and experiences of mothers in relation to reading with their children and their own reading - for example, reading homework, other activities relating to reading, the child's progress and problems in reading, reflections on the parent-assistant role, their own relationship with reading. All the interviews except one took place in the informant's home environment; in one case the interview was held in a café. All the interviews were at least partially carried out in the presence of the child and this interaction with us and the testimonies have helped me to gain a more comprehensive picture of the perception of home reading activities from the point of view of both the mother and child. The interviews were approximately 60 to 180 minutes long; they were recorded using a voice recorder and subsequently transcribed verbatim. Before and during the interviews with the mothers, I repeatedly emphasized that I would appreciate honesty in their testimonies and in hearing about their common and real everyday experiences of reading together with their children.

I analysed the interview transcripts using inductive open coding (Švaříček \& Šedová, et al., 2007) and by categorizing the individual codes, which generated categories such as "mother's aspiration", "(un)perceived problem" (see also Sedláčková, 2017) and "reflective behaviour by the mother". Since I was aware of these categories were interlinked, I decided to subject them to a more detailed analysis that would enable me to discover not only all the topics and connections the informants referred to in the relevant excerpts (e.g., failure to read worse than poor school grades, creating opportunities, etc.) but also to identify the finer details interlinking the phenomena these categories represent. From this analysis I have so far concluded that 1) the mothers' reading aspirations are intertwined with what they perceive their child's reading difficulty to be, 2) any perceived existing or potential reading difficulty has an influence on the actions undertaken to prevent or solve that problem - or specific micro-actions carried out to encourage development in specific reading literacy areas. Depending on their characteristics, I subsequently labelled the mothers' approaches using the metaphors of Inspectors, Promoters and Educators. 
However, in the context of the research as a whole, we need to bear in mind that the stimulating power of the family reading environment may be influenced by other factors apart from the mothers' reading aspirations, and that these might partly fuel them. They include some SES characteristics (mother's education level, being the sole earner, number of books in the home), as well as more subtle characteristics that are usually not linked to SES, or not directly (mothers' relationship to reading, wider family support network - see footnotes to Table 1).

I was limited by the number of pairs, which means I am unable to compare the significance of the links found, and to determine the extent to which they could be affected by the sample characteristics, including, for example, the location (the pairs live in a region where the PIRLS 2016 (Janotová, Tauberová, \& Potužníková, 2017) results show that students achieve slightly higher reading literacy results than their family background would suggest). On the other hand, the smaller number of informants meant I had the opportunity to discern and record the nuances in the relationships between the different factors of the family reading environment.

\section{Mothers' Approaches to Dealing with Their Children's Reading Difficulties}

As I have already mentioned, mothers with different reading aspirations view their child's reading difficulties as being of varying importance, and ultimately this also has a bearing on their approach to dealing with them. In the following sections, I will detail the individual approaches the mothers used to tackle the reading difficulties, and will present the activities or aspects that distinguish them from one another, and last but not least, I will show how they are linked to their mother's reading aspirations.

\section{Inspectors}

The inspector metaphor can be used to describe the approach adopted by mothers who had practical aspirations concerning reading errors, which was the problem they thought most significant. These mothers were primarily focused on operationally correcting any errors their child made when reading, as Martina states: I always take the primer, we sit down and he reads and when he makes an error I correct him. They supervise the child, checking whether the assignment is performed correctly. However, they do not assume much responsibility for developing the child's overall reading 
literacy beyond the official assignment - expanding the child's vocabulary, the amount of work done on the text or developing an interest in reading. One possible cause may be that they felt the maximum had been reached. As noted, for example, by Martina:

When he wants to practise reading books on his own, he practices I leave him to it. [...] Yeah, really, he just took that book, and ever since he has started to - so ... then it didn't matter to me. Whether he can do it or not. So I would say that, clearly, well, it's as good as it can be. (with a smile)

She is proud of her son's independence and his interest in reading - the fact he also reads in his spare time. When she saw that her son was able to handle the text on his own and did not require her assistance or explanations, she was no longer concerned about being involved in this activity. With her son's growing reading skills, her control of the reading process decreased to such an extent that she no longer cared about it, because she also felt that her son was at his maximum (she did not see how he could read any better). The absence of further ambitions is related to her satisfaction with the state of her son's reading skills, which not only corresponds to her practical aspirations, but even slightly surpasses them - as she is not particularly concerned about him forming a relationship with books. She sees it as a bonus.

Another possible reason why the Inspectors do not think it important to develop other reading literacy areas beyond acquiring reading techniques is that some of these mothers are anxious and hence reluctant to explain things, especially when the child is reading during spare time activities and not as part of homework, and it is therefore not considered to be one of their duties. Tán̆a admits:

This book, I had a Dog and a Cat, I'm finding that it's too difficult for her. She reads it, but she doesn't understand much of it. There are words she doesn't understand, let alone if I had to explain every word, what it means ... Well, that's why we did not read much of these books because she started with this one here, so I said: "For Christ's sake"... There are always expressions that I would have to explain. I don't know really. This is not my cup of tea...

Tán̆a's remark that she thought I had a Dog and a Cat was too difficult for her daughter gradually turns into a confession that she does not feel 
competent enough to explain the words used in the book. This raises questions about whether she understands them all. One can discern dismay and a certain transfixion with when her daughter came and asked her to explain. In the end she says that she does not enjoy explaining the words; perhaps she even finds it annoying. This may be because she does not understand the words, feels she is not good at expressing such things or simply becomes annoyed at having to explain unknown words that were not part of the original reading plan.

The Inspectors' lack of interest in developing other areas of reading literacy is also linked with the fact that they do not increase their demands in relation to the reading level of their children. This is noticeable if we contrast excerpts from the interview with Tána (with practical aspirations) and Danka (with developmental aspirations), in which both discuss their views on reading single- or multi-word writing on the leaflets, posters, billboards, shops for example that they often see on the streets or encounter elsewhere in their everyday lives. Táña reflects:

[When she was sick] she didn't read, but you know, it'll have an impact for sure. Especially on the r sound. But that's not to say that she didn't read at all. For instance we're driving along the road and she's trying to read the [...] signs. She won't read it for the whole five minutes, but she makes an effort.

It is only on a superficial level that Táña is concerned about the fact that she and her daughter did not read when she was sick. From her point of view, Tonička at least put in a little effort and she considers that to be sufficient. In terms of her aspirations, there is no need to motivate her daughter to read beyond her ability to read signs and to have an idea of what they mean or refer to. By contrast, Danka says: Well, the fact he reads some signs, I don't consider that reading, in fact. OK, he read the menu, so it was fine, but I don't think that's sufficient any more... Danka simply does not see his ability to read some signs as sufficient progress for the end of the second half of the school year. The progressive skill level she requires Domik to achieve during grade 1 has already been noted. In both these cases, however, the difference in the skill level required can also be explained by the fact that Tán̆a perceives Tonička to be a weak reader (she does not think her daughter is very good at reading and she may therefore place fewer demands on her progress), while Danka considers Domík to be a proficient reader (hence she may have higher demands on his reading). Martina, who has practical aspirations and considers her son to be a proficient reader, is like Tána in 
that she does not increase her demands on her son Milánek: You have to slow down so that you do not get new workbooks (amused). She is happy with his reading progress, but it is also important for her to comply with the school's instructions, and for Milánek not to stand out in class because of his reading ability to the extent that might cause problems with his teacher. This is equivalent to saying that she prefers to follow the development trajectory set by the school, and she would potentially be willing to slow down her child's progress to ensure that was the case.

The Inspector metaphor also reflects these mothers' approaches to their children's motivation to read, and how they reward them for their reading efforts. They use verbal praise which they give their children for good performance in particular reading homework. This is both confirmation and approval that the child has demonstrated sufficient skill for the next stage of the learning path. For example, Marika says: I will praise her, "good work". That's what they have been telling us to do since kindergarten, so she gets that praise. Marika claims she adopted this method of rewarding her child from the kindergarten teachers who emphasized it to the parents. Kristýna also praises her daughter: Whenever it is appropriate, I praise her, of course, and when she asks "Was that nice?" or "We read it nicely, right?" So you do want to praise her. Her daughter, Karolinka is wondering if she has read the piece properly and whether everything is fine, and Kristýna is expressing her desire to confirm that fact.

\section{Promoters}

In contrast, the mothers who had experiential aspirations concentrated on the things they can do to encourage their child's interest in reading. They mention joint activities outside the scope of homework assignments that are intended to foster their children's relationship with reading. Tamara and Tomášek talk about how they often read together and take turns to read: Tomášek: So I read the headlines and there are some other things too, such as what it is about. I always read what it is about and my mom reads everything. Tamara: And that gives us a story, is that right? We take turns. This method of working with the text together was recommended to Tamara by one of her older daughter's teachers as a means of dealing with reading problems. Tamara naturally uses it when reading with her son, for it has proven effective - it made reading more enjoyable for her daughter and now her son even insists they do it. When working with his mother, the weight of the reading activity does not lie with him alone. His mother rewards him for reading short sections of the text and then follows up, not leaving him 
"without a response". This means he can quietly listen to his mother's voice for a moment and pay full attention to the unfolding plot. This is a moment when Tamara and Tomášek can spend time together and work on a small joint project. Reading practice is more like a pre-school game, compared to the child having to read under supervision or alone without the participation of somebody else. Another Promoter activity undertaken by Tamara is supplying him with potentially interesting books from the library: Well, I at least try to go to the library, here in the village, to get them six or seven books, to see if any catch their attention, or I read from the books so that they have some kind of a relationship with books. She tries to strengthen Tomášek's relationship with reading by bringing several potentially interesting books, and then reading to him from them. Similarly, until recently Simona closely linked her reading activities to the nearby library. In the interview, she remembered with nostalgia how she and her two children used to go there before Samik started attending school (before his reading problems started) and how they read together:

Previously, we used to go to the library a lot, we borrowed books and even read from them [...] we don't really have for that. [...] We always borrowed books that were for me, my daughter and Samik, we sort of read there together. About tractors and that sort of thing. [...] We used to go there every month, we don't have time now for that.

It is quite possible that if Samik had not had reading problems, they would have continued to do this.

But, these mothers do not try to insist on their way if their child takes no interest in a particular book or reading activity - the child's still fragile interest is at stake. Tamara remembers how she got Painted Reading for Tomášek, but because it was too difficult for him to find descriptions for the pictures that would fit into the text, they abandoned that activity:

I thought to myself, well this painted reading, I will support him this way, and I got a book with large letters and pictures, but he doesn't know how to - either he has no idea what they represent or how to decline the words in the text. The pictures are really difficult for... (author's note: him to capture and turn into words) so I told him how to put them there (author's note: in the sentence). For instance, there were some words for making the sentence "I feel like crying" and a child, a little girl, crying, okay? And he goes like this: "I feel like crying a little girl", right? And I say: "What's that, I feel like crying a little girl?" And so 
I had to go and explain to him that it's "I feel like crying." So I thought, these pictures are no good yet. It was just a waste of time for us.

Since she had not been able to explain to Tomášek how to turn the pictures into the words within the sentences, or because it was too difficult for him, she stopped trying to explain it, as it was only holding Tomášek back from understanding the text and enjoying the story. Unlike Tán̆a (with her practical aspirations), Tamara does not feel uncomfortable explaining new things; she mentions having attempted to explain something - but when she failed and could not achieve her aim, she lost the motivation to continue with the book. In contrast, Simona, who also has experiential aspirations and finds it hard to deal with her son's reluctance to do his reading homework, is grateful that the bulk of support comes from the school: I am glad the school has a big share. My task is just to go through it with him again. I don't explain much or anything like that. [...] We don't feel we have to add any explanation. I think he'll catch up later anyway. She is glad the school has primary responsibility for teaching the reading techniques, or, in other words, she feels better because she can attribute that role to the school. At the same time, she adds that she does not feel the need to explain anything to Samik, which seems strange, considering how intensely she experiences her son's reading difficulties, which she thinks are preventing him from developing a relationship with reading (see Sedláčková, 2017). This approach could partly stem from her unwavering faith that Samik's reading will improve and partly from a fatal concern that by explaining things and thus prolonging the total time spent reading she would make reading even more unpleasant for her son, and any unpleasant feeling associated with reading would only add to the difficulties exacerbating his lack of interest.

As regards rewards for reading, both mothers say they use verbal praise, like the Inspector mothers; in addition, Tamara mentions the computer games he plays after reading:

I see it as positive. He finishes his assignments first, does his reading and the games are a reward. And that's what makes him look forward to it too. He actually reads without complaining, because he knows that a reward will follow. I didn't have anything to reward Rozárka with, so she cried a lot more when she had to read.

She highlights the importance of the child having something to look forward to after reading a section, since praise itself sometimes may not be enough to keep the child interested in mandatory reading homework. Chil- 
dren's efforts should be rewarded with something more appealing. Although games can be regarded as being indirectly related to reading, in this case they fulfil the function of motivating Tomášek to read.

\section{Educators}

In contrast to the Inspector mothers who simply try to keep apace of school requirements, the Educator mothers, who have developmental aspirations, do not rely merely on the school to teach reading. They take the initiative and teach their children to read themselves - they do not just repeat and practise school work. They endeavour to influence various areas of reading literacy development: reading techniques, the child's interest in reading and vocabulary. For this purpose, they create a number of learning opportunities for the child beyond sitting at home with the primer. Zuzana, for example, mentions: When she was learning the syllable --ma-- we read the encyclopaedia of mushrooms, the small, reference type, and another time she adds:

Well, as life unfolds, these situations come up or we go on a trip, we look at maps, we might go to the zoo, so we read all the names of the species and perhaps how many vertebrae a giraffe has, right, just like a human, because it is a vertebrate.

Her testimony shows the pleasure she gains from explaining and teaching her daughter things. She voluntarily takes on the role of educator in these situations: Like we didn't rely just on the school, I mean you wouldn't, not just on the school, not really. Although elsewhere she says she does not do anything extra with her daughter, compared with the Promoters who believe the child will "catch up anyway" or the Inspectors who do not pay much attention to their participation in their child's learning, but as we see this is not in fact the case. Zuzana openly expresses distrust of the school in the sense that the school could teach her daughter everything she considers important and interesting. A similar kind of engagement and reluctance to rely only on school is evident in the interview with Sofie. Sofie has three children. Adélka, the eldest, learnt to read "basically on her own" at pre-school age; therefore she expected her younger daughter Stelinka, now in grade 1, to follow a similar developmental path. She did not force her to read since she believed it would come by itself. But Stelinka's attitude to reading was a disappointment; it did not correspond to her ideas: I thought she would try harder, but she doesn't care much. That is why she decided to take a different approach with her youngest child, Vilik, still of pre-school age: 
I wrote down what it was for Vilda [Vilik], next to the picture, so he can kind of compose it (from those sewn letters). It may be premature, but it seemed fun to me, that they might have fun. [...] Just to allow him get to know these letters, to perceive them in a natural way.

In order to avoid Vilik following the same path as Stelinka and not put any effort into reading in grade 1 , she had decided to teach him the letters in advance in a playful way so that he would reach the same level as Adélka. The game was based on cloth letters that Sofie had sewn for Vilik so he could touch them, match them to pictures or make simple words out of them. Danka also spoke about creating reading opportunities when she mentioned a situation when Domik could not read a sign on the tram once and so she pointed out another one to him instead. There is also a certain flexibility in which Educator mother respond to the situations their children find themselves when learning to read.

The interviews show that of all the mothers the Educators use the widest range of activities to stimulate the various areas of reading literacy development. Like the Promoters, they also practise reading in turns, but do so even when their children do not have reading problems or lack interest. They describe doing this as shared and intimate moments when they enjoy and their children enjoy being together. Danka:

These animals that Domik means, that's something we read about a week or two ago, when we were lying in bed. I wanted to read and Domik said he wanted to read too. And so eventually I read about some animals to him and then he read about some animals to me. So it was really like (1) intimate reading.

This is where Danka becomes a model for Domík, because her desire to read sparks the same interest in Domik. Danka takes advantage of this situation and decides not to read just for herself but to read together with her son; she decides not to read aloud to him, which would also be an option, but that they will take turns to read. This time they chose a children's encyclopaedia of animals that Domik had borrowed from the library; another time they read The Hobbit, which was Danka's wish. In addition to taking turns to read, Educators also used other types of activities, such as word football (Danka, Zuzana, Sofie), exercises for developing phonemic awareness (Zuzana) or reading aloud (Sofie, Štěpánka). However, unlike the other mothers their goal was not always to find ad hoc solutions to their child's perceived problem. 
Educator mothers also mentioned a natural willingness to explain unknown words or phenomena. This willingness stemmed from the emphasis they placed on the child understanding the text and the various nuances between words, which should gradually pave the way for future development (see Sedláčková, 2017, p. 141). For example, Štěpánka stated:

So we really went over every word; we explained the meaning of that word. [...] We always explain what it means so that he understands what he is reading, because it is incredibly important that he understands what he is reading. Otherwise he won't enjoy it, it will just be about memorizing or repeating what he sees written down, but we need him to know the meaning.

Štěpanka thinks that if her son understands the text this will be key to him becoming interested in it. By carefully explaining each unknown word to him, she tries to prevent him from developing a superficial style of reading and, more broadly, of learning. At the same time, she is willing to revise or learn what she has already forgotten: I regulate everything and learn along with them, if necessary (for more detail, see Sedláčková, 2017, p. 141).

Educators sometimes engage in explaining things outside the mandatory school curriculum for that grade. Zuzana explains how she teaches Zorinka about the educational aspect of books in the activities they do:

If we don't know a word, we look for it in the dictionary, together we look it up, the fact there is a dictionary, that it has two sides, one is for this language, that language, so we taught her to look up things in books using the table of contents - she was actually just trying to find a fairy tale in the book and, which page it was on, so we taught her, but she learnt very well that there is a table of contents where she can read where it is and she recognizes the number and finds the page accordingly. She learnt this very quickly. She could not read but found the page, the fairy tale, the numbers. [...] We taught her the table of contents really early. Now I'm planning to move on to the index, in the more specialized books, so she knows that when she needs something she will find it in the index in most cases, the basic words.

She describes how she and her husband teach their daughter to find her away around and not to get lost in books and texts, whether they are fairy tales or specialized literature. Zorinka thus gains support not only in the sense of genre-rich literature, but also in the form of instructions for using it, which the other mothers did not mention (see Sedláčková, 2017, p. 141). 
All the areas the Educators develop in their children are interlinked with helping them understand, which is what their efforts are focused on (see Sedláčková, 2017, p. 141). Zuzana mentions that she carefully notes when Zorinka does not understand something or perhaps she even anticipates that she might not understand. She even considers her daughter's spare time reading with the same watchful eye:

When she is reading, she always makes a face like when she does not understand, so she pulls this face, so we explain it then or I ask: "Do you understand that?", when I think the text's too hard for her age, yeah. But I don't think this is something we came across in the primer [...] maybe some of the puzzles, when there was a kind of teaser, when we were reading something, then she had to understand it properly, so that's the time for a more thorough explanation.

She describes how carefully she monitors her daughter's non-verbal signals and continuously provides the necessary explanations, even when they aren't reading the school primer. Kristýna (with practical aspirations) mentioned being similarly attentive to any misunderstanding of the text, but only in relation to texts the teacher had assigned as homework. This again shows that mothers with different aspirations concentrate on a different range of activities related to reading literacy development (see Sedláčková, 2017, p. 141).

While the Inspectors and Promoters reward their children's reading with praise or subsequent games, the Educators also included general reading or books. Danka states that the promise of being allowed to play games only motivates her son to read sometimes, but she does not play down how important they are to her son: Perhaps the best moment would be if he came and said he was a bit bored and perhaps motivated, when he does his homework, he can play on the tablet, but she adds: But this happens about once in twenty-five attempts. But that's probably the best, well, like when the homework is done, there will be something fantastic (laughs). Domik, in Danka's words, likes reading and that he is good at it, so in order to understand why her son occasionally becomes demotivated when doing reading homework, we need to look at the way the assignments are set up, rather than at reading in general. The reading assignment is just an assignment - it is obligatory and must be done by a certain deadline and ideally he should be able to accomplish it at the appropriate level. There are too many restrictive factors here and they may not coincide with the child's momentary desire to read. If we take a wider perspective than just the reading homework, we see that 
Zuzana mentions another way in which her daughter is rewarded - a form of self-award: I let her read on her own. It is her practice time and, most importantly, she enjoys it and she tells me: "I have already read it by myself." Basically that she has managed it, right. She mentions Zorinka's joy of being able to read the text independently - she is proud of herself and can boast to her mother. The act of reading seems to have been the best reward for her. According to Zuzana, Zorinka has sufficient intrinsic motivation to read; she can just "let her daughter read", she does not have to think up any other rewards. In this way, then, as early as in grade 1, reading became a natural part of her daughter's life. The question is to what extent this interest in reading is about personality and to what extent it is the outcome of all the things Zuzana does to get her daughter accustomed to reading and how she guides her, starting with the fact that she has been presenting reading to her as a reward from the very beginning: We told her she would actually be able to read during the first grade, that she would read by herself there too, right, which is also very motivating, that she wouldn't have to depend on us, but would be able to read on her own... she won't have to come and ask us. She promises her daughter that when she learns to read, she will be independent, "a big girl", and that her skills will eventually match those of adults. She therefore sees learning to read as a step by step initiation ritual into the adult world. Štépánka, on the other hand, rewarded Šimonek's reading efforts by giving him a new book. Here Štěpánka and Šimonek are talking about ordering books from the current catalogue going round his class:

Šimonek: I'm really interested in this, like if I choose one, I'll choose loads of Minecraft.

Štěpánka: No, honey, not loads of Minecraft, you're only going to read one, and if you take too long to read it - you know what, Šimi [Šimonek], we won't be buying five books just for the sake of buying five books. We'll buy one and when you've finished it, we can look at buying another one, okay?

By limiting the number of books they buy, she creates tension: when he finishes the first volume about Minecraft (and by an unspecified but fastapproaching date), she can buy him another one. She uses the book as a convenient way of thematically rewarding his potential reading efforts reading the book independently (mastering the technique) and finishing it within a certain time limit (creating pressure on him to complete the activity: Šimonek not only has to read the book but also has to finish it, within a specific time frame, in the hope that Štěpánka will buy him another - he has to have worked for it). The book is portrayed as a trophy that Šimonek 
has to fight for - not as something that he has to do out of a sense of duty. Štěpánka is ingeniously exploiting her knowledge of her son. He is keen on Minecraft, and she uses his desire for her own and potentially his benefit too. This type of support was typical of Educator mothers.

\section{Conclusions and Discussion}

In this study, I have looked at how mothers of first graders deal with their perceived children's reading difficulties. Their understanding of what may or may not be a reading difficulty appears to be closely related to the reading aspirations they have for their children (Sedláčková, 2017). In this study, I have described the aspects that characterize the mothers' approaches to the perceived reading problems and, on that basis, created apt metaphors to reflect the type of mother. The resulting typology could be beneficial both for discussions between grade 1 elementary school teachers and parents and in counselling. Having an in-depth knowledge of parents' needs and what they do to develop their children's reading literacy will make it easier to formulate suggestions on how this can be fostered and improved, which in turn could have an impact on student achievement.

Inspector mothers (with practical aspirations), who view their children's reading errors as a major problem, indicated that they directly corrected their child's errors, but did not explain much - either because they felt the child was otherwise doing well, and therefore greater explanation was not needed, or because they did not like explaining things and did not feel fully competent in doing so. Promoter mothers (with experiential aspirations), who are most concerned about their children's lack of interest in reading, respond to this perceived problem by reading in turns to make reading easier and more pleasant for the child. If the child expresses an interest in reading then children's books are borrowed from the library as encouragement. All the activities aimed at fostering the child's reading literacy development are initially tested and then carefully introduced in order to stimulate and not demotivate the child's interest in reading, and this determines whether these activities appear on the daily agenda again. Educator mothers (with developmental aspirations), who fear most that their child will not understand the text (which could jeopardize and inhibit reading skills as a value for further development), try to introduce precautionary measures, such as creating opportunities in which the various areas of reading literacy can be developed, both during homework and leisure time reading. This may include responsive or anticipatory explanations, as well as motivating the child to read through the act of reading. 
The study elaborates on the conclusions of a survey carried out by Sotáková (in Kucharská, 2016), in which she subjects the questionnaire statements of 41 parents of grade 1 children to a quantitative analysis. Sotáková states that parents do not always have the information they require to promote level-appropriate reading in the child. The conclusions of my study are essentially in line with this, as regardless of their reading aspirations, the mothers mentioned an occasional sense of uncertainty regarding appropriate methods for developing their children's reading literacy. However, the way they dealt with this varied: while the Educators mentioned a tendency to keep track of approximately which reading development stage their children were in and would not hesitate to familiarise themselves with the subject matter, mothers with other approaches simply tended to mention their uncertainty without indicating any real attempt to overcome $i^{7}$. This could be explained in terms of their perceived limits.

The findings of my study can be explained using self-termination theory (Ryan \& Deci, 2017; Wild, 1999 in Yotyodying \& Wild, 2014, pp. 98-99, cf. also Cunha et al., 2015). The Educators mentioned encouraging their child's reading autonomy whilst sensitively responding to them, and providing a clear structure in the form of explicit rules for learning situations and clear expectations. The control dimension related not only to homework reading tasks; the mothers admitted giving guidance during leisure-time reading. The Inspectors and Promoters had characteristics that differed from those of the Educators - most clearly in the control dimension, which almost exclusively concerned the mandatory reading homework. One can also see sensitive responding to the child's reading in the Promoters testimonies, but not in the Inspectors testimonies. Autonomy is mentioned by the Promoters in relation to leisure reading and can be found throughout the Inspectors testimonies; however, since it is unintentional it raises the question of the extent to which this can be viewed as the "promotion" of autonomy. Nonetheless, one cannot conclude the discussion by arguing that the Inspectors and Promoters do not relate to reading; it is just that the way they do so diverges from what the school prescribes. In view of the conclusions of, for example, Silinskas et al. (2013), there is greatest potential for the Educators' behaviour to impact on their children's reading skills (regardless of other factors that may be involved). However, it would be necessary to examine whether the same holds for children's interest in reading, which partly tran-

Hume, Lonigan, and McQueen (2015) point to the need to distinguish nuances in engagement in the context of reading literacy development: they argue that parental activities such as exposing children to literacy and teaching them literacy concepts appear to be different constructs. 
scends the concept of skills, and the qualitative characteristics this interest exhibits, and whether it is potentially shaped by the school in the long term.

The extent to which the school directs parental influence through its own requirements (cf. also Gorčíková \& Šafr, 2016; Hegedaard, 2014) may also be perceived differently by different parents, and according to reading aspiration. The Educator mothers I surveyed stated that they did not expect the child to acquire all reading literacy content in school. By contrast, the Inspectors and Promoters were glad that, as they saw it, most of this responsibility lay with the school - they did not accept that they had any share in this responsibility, with the partial exception of supervising reading homework and fostering the child's interest in reading, which they often considered "optional". With this in mind, the first group of mothers could be labelled "engaged", and the other "involved", since the participation of the first group is basically spontaneous, while the second group's tends to be intervention-based (see Desforges \& Abouchaar, 2003).

My conclusions do not indicate much correspondence with the conclusions of Sacker et al. (2002 in Desforges \& Abouchaar, 2003) that state that parental expectations automatically increase in relation to the child's progress: notwithstanding the fact that mothers with practical aspirations aimed lower than those with developmental ones, the mothers I surveyed did not mention raising requirements, even when their child progressed, which could indicate their expectations of them had not changed either. At the same time, it could mean that parental approaches are more strongly influenced by their own reading aspirations than, for example, by their children's reading difficulties or results.

As in the Lynch et al. study (2006), the aspirations of the mothers in my study are also interlinked with the way they help their children learn to read. Within the discussion about the role played by the education level or, more broadly, the socioeconomic status of the mother in the quality of their involvement in the activities of reading literacy development (see, in particular, Niklas \& Schenider, 2013, cf. Gorčíková \& Šafr, 2016) may be worth considering whether type of reading aspiration paves the way for the various formalized reading activities and behaviours through which this influence is manifested. The data obtained supported the thesis that socioeconomic status has an indirect influence on the quality of the home reading environment. However, the question is to what extent can mothers' approaches, reading aspirations, and quality of home reading environment generally be explained by education level and material conditions and to what extent are 
these influenced by factors that could be unrelated to socioeconomic status, such as mothers' relationship to reading or wider family support network? This question require further investigation in order to get know or rethink if it could be good to include also these factors into blanket comparative questionnaires.

In contrast to the 2016 PIRLS survey (Janotová, Tauberová \& Potužníková, 2017) which assessed student reading literacy in terms of reading purpose: 1) to gain literary experience (reading for interest/pleasure) and 2) to obtain and use information (as an educative tool), the data acquired in this study show that the mothers tended to distinguish three different reading purposes, as they did not necessarily view gaining and using information as being the same as a learning tool. Reading for interest and reading for pleasure can be seen as partly separate from other purposes. The mothers' view did not exactly correspond to the category of "reading for the acquisition of literary experience" because they are not so concerned about the child merely acquiring more experience but about the nature of that experience. However, given there were fewer mothers with experiential aspirations in the sample, we can ask to what extent do mothers of first graders consider reading for pleasure to be an important priority, compared to other reading purposes. (As Ronková and Laufková (2017) point out, in the Czech Republic little emphasis is placed on reading for pleasure in comparison with other European countries and students are less motivated to read for pleasure or to choose books for reading according to their own interest).

Considering the importance of relationship to reading for reading literacy development, and the fact that parents can influence this relationship at both preschool age and at the beginning of schooling, we might infer from what has been discussed that Czech parents should not stop motivating their children to read once they start school, as it is a pleasurable activity (not just a means of gaining information or promoting development), and that they should not focus on children with reading difficulties and neglect those who are proficient readers or show an interest in reading (see Trávniček, 2007). This recommendation is aimed at ensuring the child's relationship to reading follows a continuum, where the foundations are laid at preschool age, supported during the crucial reading instruction provided in grades 1 and 2 and then expanded on later - so that the gap in the often fragile interest of the child in reading can be safely bridged during the transition period. 


\section{References}

Audet, D., Evans, M. A., Williamson, K., \& Reynolds, K. (2008). Shared book reading: Parental goals across the primary grades and goal-behavior relationships in junior kindergarten. Early Education and Development, 19(1), 112-137.

Baker, L., \& Scher, D. (2002). Beginning reader's motivation for reading in relation to parental beliefs and home reading experiences. Reading Psychology, 23(4), 239-269. Bhattacherjee, A. (2012). Social science research: Principles, methods, and practices. Tampa: University of South Florida.

Bonifacci, P., Montuschi, M., Lami, L., \& Snowling, M. J. (2014). Parents of children with dyslexia: Cognitive, emotional and behavioural profile. Dyslexia, 20(2), 175-190. Case, L. P., Speece, D. L., Silverman, R., Ritchey, K. D., Schatschneider, C., Cooper, D. H., Montanaro, E., \& Jacobs, D. (2010). Validation of a supplemental reading intervention for first-grade children. Journal of Learning Disabilities, 43(5), 402-417. Clingenpeel, B. T., \& Pianta, R. C. (2007). Mothers' sensitivity and book-reading interactions with first-grades. Early Education and Development, 18(1), 1-22.

Cunha, J., Rosário, P., Macedo, L., Nunes, A. R., Fuentes, S., Pinto, R., \& Suárez, N. (2015). Parents' conceptions of their homework involvement in elementary school. Psicothema, 27(2), 159-165.

Da Silva, E. A. (2017). Literacy as „reading the world“: The construction of a socially situated concept in a school context. Calidoscopio, 15(1), 57-70.

Desforges, Ch., \& Abouchaar, A. (2003). The impact of parental involvement, parental support and family education on pupil achievements and adjustment. Department for Education and Skills: Queen's Printer.

Domenech, M., \& Krah, A. (2014). Which familial aspects matter? Investigating argumentative competencies by learners at the beginning of secondary schooling in the light of family-based resources. Learning, Culture and Social Interaction, 3(2), 77-87. Dumont, H., Trautwein, U., Nagy, G., \& Nagengast, B. (2014). Quality of parental homework involvement: Predictors and reciprocal relations with academic functioning in the reading domain. Journal of Educational Psychology, 106(1), 144-161.

Eurydice. (2011). Teaching reading in Europe: Concepts, policies and practices. Brussels: EACEA.

Fan, Q. (2012). Parents'perceptions and practices in homework: Implications for school-teacher-parent partnerships (Dissertation). Available at: indigo.uic.edu/handle/ $10027 / 9727$

Froiland, J. M. (2011). Parental autonomy support and student learning goals: A preliminary examination of an intrinsic motivation intervention. Child \& Youth Care Forum, 40(2), 135-149.

Gonida, E. N., \& Cortina, K. S. (2014). Parental homework involvement: Relations with parent and student achievement-related motivational beliefs and achievement. British Journal of Educational Psychology, 84(3), 376-396.

Gorčiková, M., \& Šafr, J. (2016). Interakce dětí s rodiči a vývoj rané čtenářské gramotnosti na počátku školní docházky. Československá psychologie, 60(1), 86-95.

Gough, P. B. (1996). How children learn to read and why they fail. Annals of Dyslexia, 46(1), 1-20.

Hegedaard, M. (2014). The signifikance of demands and motives across practices in 
children's learning and development: An analysis of learning in home and school. Learning, Culture and Social Interaction, 3(3), 188-194.

Hoover-Dempsey, K. V., \& Sandler, H. M. (1995). Parental involvement in children's education: Why does it make a difference? Teachers College Record, 97(2), 310331.

Hoover-Dempsey, K. V., \& Sandler, H. M. (1997). Why do parents become involved in their children's education? Review of Educational Research, 67(1), 3-42.

Hughes, M. T., Schumm, J. S., \& Vaughn, S. (1999). Home literacy activities: Perceptions and practices of hispanic parents of chldren with learning disabilities. Learning Disability Quarterly, 22(3), 224-235.

Hume, L. E., Lonigan, Ch. J., \& McQueen, J. D. (2015). Children's literacy interest and its relations to parents' literacy-promoting practices. Journal of Research in Reading, 38(2), 172-193.

Janotová, Z., Tauberová, D., \& Potužníková, E. (2017). Mezinárodní šetření PIRLS 2016: Národni zpráva. Praha: ČS̆I.

Johnson, E., Bornman, J., \& Alant, E. (2010). Parents'perceptions of home reading activities: Comparing children with and without learning disability. Perspectives in Education, 28(1), 34-43.

Katrñák, T. (2004). Odsouzeni k manuální práci: vzdělanostní reprodukce v dělnické rodinè. Praha: Sociologické nakladatelství.

Kiuru, N., Aunola, K., Torppa, M., Lerkkanen, M.-K., Poikkeus, A.-M., Niemi, P., Viljaranta, J., Lyyra, A.-L., Leskinen, E., Tolvanen, A. \& Nurmi, J.-E. (2012). The role of parenting styles and teacher interactional styles in children's reading and spelling development. Journal of School Psychology, 50(6), 799-823.

Klicpera, B. G., Klicpera, C., \& Schabmann, A. (2001). Perceptions of the problems of poor readers and spellers by the parents - Pygmalion in the living room? Praxis der Kinderpsychologie und Kinderpsychiatrie, 50(8), 622-639.

Kucharská, A., \& Seidlová Málková, G. (2012). Čtenářská gramotnost - předpoklady rozvoje, počáteční gramotnost. Pedagogika, 62(1-2), 1-9.

Kucharská, A., et al. (2015). Porozumění čtenému III. Praha: PdF UK.

Law, J. M., Vandermosten, M., Ghesquière, P, \& Wouters, J. (2017). Predicting future reading problems based on pre-reading auditory measures: A longitudinal study of children with a familial risk of dyslexia. Frontiers in Psychology, 8(Issue FEB).

Leseman, P. P. M., de Jong, P. F. (1998). Home literacy: Opportunity, instruction, cooperation and social-emotional quality predicting early reading achievement. Reading Research Quarterly, 33(3), 294-318.

Lynch, J., Anderson, J., Anderson, A., \& Shapiro, J. (2006). Parents‘ beliefs about young children's literacy development and parents' lieracy behaviors. Reading Psychology, 27(1), 1-20.

Mareš, J., Průcha, J., \& Walterová, E. (2003). Pedagogický slouník. Praha: Portál. Maxwell, J. A., \& Mittapalli, K. (2008). Explanatory research. In L. M. Given: The SAGE encyclopedia of qualitative research methods (pp. 324-325). Thousand Oaks: SAGE Publications, Ltd.

Mertin, V. (2010). Podpora a rozvoj čtenářských dovedností v předškolním věku. In V. Mertin, \& I. Gillernová (Eds.), Psychologie pro učitelky mateřské školy (pp. 163172). Praha: Portál. 
Najvarová, V. (2008). Čtenářská gramotnost žáků 1. stupně základní školy (Dissertation). Available at: http://is.muni.cz/th/14647/?lang=en

Ndebele, M. (2015). Socio-economic factors affecting parrents involvement in homework: Practices and perceptions from eight Johannesburg public primary schools. Perspectives in Education, 33(3), 72-91.

Niklas, F., \& Schneider, W. (2013). Home literacy environment and the beginning of reading and spelling. Contemporary Educational Psychology, 38(1), 40-50.

Pospíšilová, R. (2011). Role rodičů v domácí připravě do školy. Studia paedagogica, 16(2), 171-182.

Presslerová, P., \& Kucharská, A. (2017). Rodičovská perspektiva variability vývoje počáteční čtenářské gramotnosti u dětí s rizikem vzniku specifických poruch učení. Gramotnost, pregramotnost a vzdèláváni, 1(2), 65-77.

Rabušicová, M. (2002). Gramotnost: Staré téma v novém pohledu. Brno: Masarykova univerzita \& Nakladatelství Georgetown.

Rabušicová, M., Šed’ová, K., Trnková, K., \& Čiháček, V. (2004). Škola a (versus) rodina. Brno: Masarykova univerzita.

Renshaw, P. D., \& Gardner, R. (1990). Process versus product task interpretation and parental teaching practice. International Journal of Behavioral Development, 13(4), 489-505.

Ronková, J., \& Laufková, V. (2017). Čtenářská gramotnost v pojetí projektu ELINET. Gramotnost, pregramotnost a vzdẽlávání, 1(1), 87-102.

Ryan, R. M., \& Deci, E. L. (2017). Self-determination theory: Basic psychological needs in motivation, development, and wellness. New York: Guilford Publishing.

Sedláčková, J. (2017). Osvojování dovednosti čtení očima matek žáků 1. třídy. Studia paedagogica, 22(3), 121-148.

Sénéchal, M., \& LeFevre, J.-A. (2014). Continuity and change in the home literacy environment as predictors of growth in vocabulary and reading. Child Development, 85(4), 1552-1568.

Siegel, L. S. (2006). Perspectives on dyslexia. Paediatrics and Child Health, 11(9). 581-587.

Silinskas, G., Kiuru, N., Tolvanen, A., Niemi, P., Lerkkanen, M.-K., \& Nurmi, J.-E. (2013). Maternal teaching of reading and children's reading skills in Grade 1: Patterns and predictors of positive and negative associations. Learning and Individual Differences, 27, 54-66.

Silinskas, G., Leppanen, U., Aunola, K., Parrila, R., \& Nurmi, J.-E. (2010). Predictors of mothers' and fathers' teaching of reading and mathematics during kindergarten and Grade 1. Learning and Instruction, 20(1), 61-71.

Speece, D. L., \& Ritchey, K. D. (2005). A longitudinal study of development of oral reading fluency in young children at risk for reading failure. Journal of Learning Disabilities, 38(5), 387-399.

Speece, D. L., Ritchey, K. D, Silverman, R., Schatschneider, C., Walker, C. Y, \& Andrusik, K. N. (2010). Identifying children in middle childhood who are at risk for reading problems. School Psychology Review, 39(2), 258-276.

Speece, D. L., Schatschneider, C., Silverman, R., Case, L. P., Cooper, D. H., \& Jacobs, D. M. (2011). Identification of reading problems in first grade within a response-to-intervention Framework. Elementary School Journal, 111 (4), 585-607. 
Stainthorp, R., \& Hughes, C. (2000). Family literacy activities in the homes of successful young readers. Journal of Research in Reading, 23(1), 41-45.

Stebbins, R. A. (2001). Exploratory research in the social sciences. New York: SAGE Publications, Inc.

Stephenson, K. A., Parrila, R. K., Georgiou, G. K., \& Kirby, J. R. (2008). Effects of home literacy, parents' beliefs, and children's task-focused behavior on emergent literacy and word reading skills. Scientific Studies of Reading, 12(1), 24-50.

Stuart, M., Dixon, M, Masterson, J., \& Quinlan, P. (1998). Learning to read at home and at school. British Journal of Educational Psychology, 68(1), 3-14.

Šauerová, M. (2012). Vliv vývoje sociálních interakcí dětí mladšího školního věku na možnosti podpory čtenářské gramotnosti v rodinné edukaci. Pedagogika, (1-2), $126-136$.

Švařiček, R., \& Šed’ová, K., et al. (2007). Kvalitativní výzkum v pedagogických vědách. Praha: Portál.

Švrčková, M., \& Šimik, O. (2012). Kvalita počáteční čtenářské gramotnosti žáků 2. ročníku ZŠ. Pedagogika, 62(1-2), 53-64.

Trávníček, J. (2007). Čteme?: Obyvatelé České republiky a jejich vztah ke knize. Brno: Host.

Van Steensel, R. (2006). Relations between socio-cultural factors, the home literacy environment and children's literacy development in the first years of primary education. Journal of Research in Reading, 29(4), 367-382.

Vellutino, F. R., Fletcher, J. M., Snowling, M. J., \& Scanlon, D. M. (2004). Specific reading disability (dyslexia): What have we learned in the past four decades? Journal of Child Psychilogy and Psychiatry and Allied Disciplines, 45(1), 2-40.

Výzkumný ústav pedagogický v Praze. (2011a). Čtenářská gramotnost ve výuce: Metodická přiručka. Praha.

Výzkumný ústav pedagogický v Praze. (2011b). Gramotnosti ve vzdělávání: Soubor studii. Praha.

Walker, J. M., Wilkins, A. S., Dallaire, J., Sandler, H. M., \& Hoover-Dempsey, K. V. (2005). Parental engagement: Model revision through scale development. The Elementary School Journal, 106(2), 85-104.

Wildová, R. (2012a). Čtenářská gramotnost v evropském kontextu. Pedagogika, 57(1-2), 45-52.

Wildová, R. (2012b). Rozvoj pregramotnosti a počáteční čtenářské gramotnosti v kurikulu evropských zemí. Pedagogika, 62(1-2), 10-21.

Wildová, R., Kropáčková, J., \& Kucharská, A. (2014). Pojetí a rozvoj čtenářské pregramotnosti v předškolním období. Pedagogická orientace, 24(4), 488-509.

Wu, Ch.-Ch., \& Honig, A. S. (2010). Taiwanese mothers' beliefs about reading aloud with preschoolers: Findings from the parent reading belief inventory. Early Child Development and Care, 180(5), 647-669.

Yeo, L. S., Ong, W. W., \& Ng, Ch. M. (2014). The home literacy and preschool children's reading skills and interest. Early Education and Development, 25(6), 791-814. Yotyodying, S., \& Wild, E. (2014). Antecedents od different qualities of home-based parental involvement: Findings from a cross-cultural study in Germany and Thailand. Learning, Culture and Social Interaction, 3(2), 98-110. 
Yubero Jimenéz, S., \& Larrañaga Rubio, E. (2010). The value of reading in relation to reading behavior. A study on reading habits and lifestyles in children. OCNOS, (10), 7-20.

\section{Author:}

Mgr. Jana Sedláčková

Masaryk University

Faculty of Arts

Department of Educational Sciences

Arna Nováka 1

Brno

60200

Czech Republic

E-mail: j.sedlackova@mail.muni.cz 